\title{
Now Look What You've Done, COVID-19! The Impact on Academic Survival among Postgraduate Students in Malaysia
}

Mohammad Izzamil Mohd Nasir, Muhammad Wafi Ramli \& Sofia Haminah Mohd Som

To Link this Article: http://dx.doi.org/10.6007/IJARBSS/v11-i2/8430

DOI:10.6007/IJARBSS/v11-i2/8430

Received: 21 December 2020, Revised: 23 January 2021, Accepted: 18 February 2021

Published Online: 27 February 2021

In-Text Citation: (Nasir et al., 2021)

To Cite this Article: Nasir, M. I. M., Ramli, M. W., \& Som, S. H. M. (2021). Now Look What You've Done, COVID19 ! The Impact on Academic Survival among Postgraduate Students in Malaysia. International Journal of Academic Research in Business and Social Sciences, 11(2), 604-618.

Copyright: (c) 2021 The Author(s)

Published by Human Resource Management Academic Research Society (www.hrmars.com)

This article is published under the Creative Commons Attribution (CC BY 4.0) license. Anyone may reproduce, distribute, translate and create derivative works of this article (for both commercial and non-commercial purposes), subject to full attribution to the original publication and authors. The full terms of this license may be seen at: http://creativecommons.org/licences/by/4.0/legalcode

Vol. 11, No. 2, 2021, Pg. 604 - 618

Full Terms \& Conditions of access and use can be found at http://hrmars.com/index.php/pages/detail/publication-ethics 


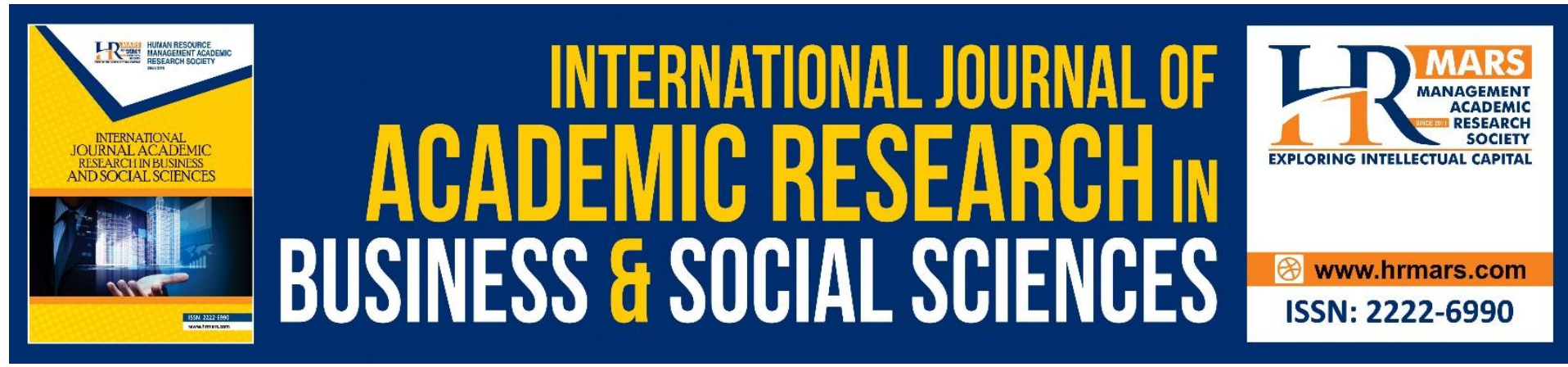

\title{
Now Look What You've Done, COVID-19! The Impact on Academic Survival among Postgraduate Students in Malaysia
}

\section{Mohammad Izzamil Mohd Nasir, Muhammad Wafi Ramli \& Sofia Haminah Mohd Som}

Geograhpy Section, School of Humanities, Universiti Sains Malaysia, 11800 Penang, Malaysia Email: izzamilmn@gmail.com

\begin{abstract}
The COVID-19 pandemic has led to the closure of various sectors in Malaysia including the education sector. The COVID-19 pandemic caused major concerns among postgraduate students. Little is known about the academic survival impacts of COVID-19 among tertiary students, especially among the postgraduates. Therefore, this article aims to identify the impact of COVID-19 pandemic on academic survival among postgraduate students in Malaysia. An online survey through Google Form is conducted in October 2020, participated by a total of 606 postgraduate students from different backgrounds. Several postgraduate students have high level of social relationships; however, they are facing problems in terms of academic performance and financial stress. This study suggests that strategies and actions are urgently needed between the higher education ministry and universities to ensure the academic survival among postgraduate students amid the pandemic.
\end{abstract}

Keywords: Academic Survival, COVID-19 Pandemic, Postgraduate Students, Malaysia

Introduction

The novel coronavirus disease (COVID-19) first occurred in Wuhan, China in December 2019 and the rapid spread of COVID-19 called the World Health Organization (WHO) to declare it as pandemic on 11 March 2020 (WHO, 2020; Kapasia et al., 2020). Since its outbreak, universities all around the world have to shut down their campuses so that students could follow social distancing measures (Toquero, 2020) and COVID-19 has posed a threat to both mental and physical health among societies as well as university students (Khan et al., 2020; Mpungose, 2020). Therefore, education at all levels, including both undergraduate and postgraduate level, have been significantly affected and had interrupted the learning of more than one billion students in 129 countries around the globe (Mostafa, 2020; UNESCO, 2020). Many universities around the world have either postponed or cancelled all campus activities to minimize gatherings and therefore help to decrease the transmission of the pandemic (Mahdy, 2020). Most countries have stopped face-to-face teaching (UNESCO IESALC, 2020) and currently replacing it with online solutions wherever practicable (Gonzalez et al., 2020) which has been a challenging task to do (Mahmood, 2020). Many areas are affected 
worldwide and there is a fear of losing this whole ongoing semester or even more in the coming future (Dhawan, 2020).

The first COVID-19 positive case was detected in Malaysia on 24 January 2020. After that, the number of cases increased in the following months (Dawood et al., 2020). Currently, as of 12 January 2021, Malaysia has reported 141,533 cases and 559 death cases (Ministry of Health Malaysia, 2021). On 18 March 2020, a nationwide 'Movement Control Order' (MCO) aimed to control the pandemic was declared, followed by Enhanced Movement Control Order (EMCO) on 27 March 2020 at the affected locations, Semi Enhanced Movement Control Order (SEMCO) on 14 May 2020, Conditional Movement Control Order (CMCO) on 1 May 2020, and Recovery Movement Control Order (RMCO) phase which started on 10 June 2020 and scheduled to 31 December 2020. Recently, the government has announced that the RMCO will be extended until 31 March 2021 and another MCO to several states in Malaysia from 13 January 2021 for two weeks.

According to Kapasia et al. (2020), the closure of educational institutions due to the pandemic outbreaks has led to an unprecedented impact on education and academic survival among students. Hussiin (2020) asserted that COVID-19 has indeed affected students in multiple aspects, including financial, academic, time management, and health. Aristovnik et al. (2020) stated that students are among the population groups that had experienced dramatic effects of the first wave of the pandemic in the first 4 or 5 months of 2020, and therefore causing huge changes to their everyday lives, and perhaps even more alarmingly, to the prospects of their immediate and distant future. The end date of the pandemic is yet to be discovered, therefore educational institutions around the world have decided to use available technical resources to create online learning materials for students from all academic fields (Kaur, 2020). This not only facilitate students to study anytime, but also to get feedback immediately (Chyr et al., 2017). Moreover, the online platform will be beneficial to encourage academic staffs to continue their give-and-take actions to keep the dynamic sustainable development for online learning development (Kong, 2019). As an emergency measure to reduce the spread of the pandemic, most higher education institutions in Malaysia are closed and they are limiting the number of student admissions. Currently, the process of teaching and learning are done online until a time that will be determined later by the Ministry of Higher Education Malaysia (MOHE) (Shahzad et al., 2020).

To date, only a few studies have been conducted on the effects of COVID-19 towards educational issues in Malaysia. For instance, there are studies about online teaching and learning for tertiary education (Chung et al., 2020; Nik-Ahmad-Zuky et al., 2020; Salleh et al., 2020), perception of e-learning (Ana et al., 2020), psychological impact among university students (Sundarasen et al., 2020) and online purchase intention among university students (Al-Hassani et al., 2020). However, studies focusing on postgraduate students in Malaysia is yet to be conducted. According to Grubic et al. (2020), studies investigating the impact of COVID-19 on students are notably needed. Accordingly, this study aims to identify the impact of academic survival among postgraduate students in Malaysia. The finding of this study is expected to extend the current literature and to provide insights for Malaysian higher education institutions in assisting postgraduate students in times like this in the future. 


\section{Methods \\ Participants}

This study was carried out using convenience and purposive sampling method, involving 606 respondents consisting of Malaysian postgraduate students.

\section{Instrument}

An online survey form was used as an instrument to obtain the primary data. The questionnaire consisted of four constructs, namely (i) respondent's profiles, which surveyed respondents' socio-demographic information, including age, nationality, gender, monthly income, source of income, level of education, types, mode and year of study, field of study, type of higher education institute, university region, and residential area; (ii) academic condition, (iii) financial constraints, and (iv) social relations. The instrument has been developed and adopted based on Kapasia et al. (2020) and Wang and DeLaquil (2020). This instrument employs a Likert-type scale of 1-5; "1 = Strongly Disagree", "2 = Disagree", "3 = Not Sure", " 4 = Agree", " 5 = Strongly Agree". The survey form was created using Google Forms and distributed online. The survey distribution was done from 15th October to 22nd October 2020 by sharing the Google Forms link to all postgraduate students via email, WhatsApp, Twitter, and Facebook. Along with the link, a standardised general description about the survey was provided in the social media postings and WhatsApp messages, both in Malay and English versions of the questionnaire. Adhering to research ethics, all respondents were asked to participate in this survey voluntarily without coercion and assured that their anonymity and confidentiality will always be maintained.

\section{Statistical Analysis}

The data were analysed using IBM Statistical Package for the Social Sciences (SPSS) software version 26.0. Most of the data were analysed using descriptive statistical analysis to obtain the values of frequency, percentage, mean, standard deviation, and correlation analysis. The interpretation scale by Landell (1997) was applied to determine the level of score for each mean value, namely low level (1.00 - 2.33), moderate level (2.34 - 3.67) and high level (3.68 - 5.00). A correlation analysis was then performed to test the associations among all three variables in the study. The analysis and tabulation of data is presented in each section accordingly.

\section{Result and Discussion Respondent's Profile}

The study successfully recruited a total of 606 respondents. The profile of the respondents is shown in Table 1 . Among the 606 respondents, $(97.2 \%, n=589$ ) were Malaysian and while the other $(2.8 \%, n=17)$ were non-Malaysian. The respondents were predominantly female, $(75.9 \%, n=454)$ as compared to male, $(25.1 \%, n=152)$. The findings showed that a large number of the respondents $(32.8 \%, n=199)$ were aged between 26-30 years old, followed by $(26.9 \%, n=163)$ aged between $31-35$ years old, and $(14.2 \%, n=86)$ aged between 36-40. In terms of education level, $(59.7 \%, n=362)$ were Ph.D. students and another $(40.3 \%, n=244)$ of the respondents were Master's Degree students by research (73.8\%, $n=447)$, coursework $(16.2 \%, n=98)$, and mix-mode $(10.1 \%, n=61)$. Meanwhile, in the distribution of study mode, the majority of the respondents $(80.7 \%, n=489)$ were fulltime students and only $(19.3 \%, n=117)$ were part-time students mainly consisting of $(33.8 \%$, $n=205)$ second year students, followed by first year $(25.9 \%, n=157)$, third year $(21.9 \%, n=$ 
$133)$, fifth year $(9.7 \%, n=59)$ and fourth year $(8.6 \%, n=52)$ students. It is also worth to note that majority of the respondents $(71.5 \%, n=433$ ) were from B40 (bottom $40 \%$ - less than MYR $4,850)$ income group, followed by $(25.1 \%, n=152)$ from M40 (Middle $40 \%$ - between MYR 4,851 and MYR 10,959) income group, and $(3.5 \%, n=21)$ from T20 (Top $20 \%$ - more than MYR $10,959)$ income group. Other demographic characteristics are detailed in Table 1.

Table 1. Respondent's profile

\begin{tabular}{|c|c|c|}
\hline Variable & $\begin{array}{c}\text { No. of } \\
\text { Respondents (f) }\end{array}$ & $\begin{array}{c}\text { Percentage } \\
\text { (\%) }\end{array}$ \\
\hline \multicolumn{3}{|l|}{ Nationality } \\
\hline Malaysian & 589 & 97.2 \\
\hline Non-Malaysian & 17 & 2.8 \\
\hline \multicolumn{3}{|l|}{ Gender } \\
\hline Male & 152 & 25.1 \\
\hline Female & 454 & 74.9 \\
\hline \multicolumn{3}{|l|}{ Age (years old) } \\
\hline$<25$ & 84 & 13.9 \\
\hline $26-30$ & 199 & 32.8 \\
\hline $31-35$ & 163 & 26.9 \\
\hline $36-40$ & 86 & 14.2 \\
\hline $41-45$ & 51 & 8.4 \\
\hline $46-50$ & 15 & 2.5 \\
\hline$>50$ & 8 & 1.3 \\
\hline \multicolumn{3}{|l|}{ Level of Education } \\
\hline Master's Degree & 244 & 40.3 \\
\hline Ph.D. & 362 & 59.7 \\
\hline \multicolumn{3}{|l|}{ Monthly Income } \\
\hline B40 (< MYR 4850) & 433 & 71.5 \\
\hline M40 (MYR 4851 - 10959) & 152 & 25.1 \\
\hline T20 (< MYR 10959) & 21 & 3.5 \\
\hline \multicolumn{3}{|l|}{ Source of Income } \\
\hline Part-time job & 62 & 10.2 \\
\hline Full time job & 185 & 30.5 \\
\hline Scholarship & 152 & 25.1 \\
\hline Study loan & 62 & 10.2 \\
\hline Family/Spouse & 145 & 23.9 \\
\hline \multicolumn{3}{|l|}{ Program } \\
\hline Coursework & 98 & 16.2 \\
\hline Mix-mode & 61 & 10.1 \\
\hline Research & 447 & 73.8 \\
\hline \multicolumn{3}{|l|}{ Mode of Study } \\
\hline Full time & 489 & 80.7 \\
\hline Part-time & 117 & 19.3 \\
\hline \multicolumn{3}{|l|}{ Year of Study } \\
\hline 1 & 157 & 25.9 \\
\hline 2 & 205 & 33.8 \\
\hline 3 & 133 & 21.9 \\
\hline
\end{tabular}


4

5

Field of Study

Engineering

Health

Applied Science

Pure Science

Pure Arts

Applied Arts

Others

Higher Education Institution (HEI)

Public

Private

Region of HEls

East Coast of Peninsular

Malaysia

Sabah/Sarawak

Southern of Peninsular

Malaysia

Central

Northern of Peninsular

Malaysia

Residential Area

Urban area

Rural area
52

59

8.6

9.7

70

52

106

59

36

43

240

570

36

44

43

72

293

154

474

132
11.6

8.6

17.5

9.7

5.9

7.1

39.6

94.1

5.9

7.3

7.1

11.9

48.3

25.4

78.2

\section{Academic Performance during COVID-19 Pandemic}

Table 2 below shows eight items on academic performance during COVID-19 pandemic. Based on the table, respondents had moderate and only one high agreement with academic performance, showing mean values from 2.88 to 3.79. Majority of the respondents are facing difficulties in collecting data for their research, with $(\mu=3.79, \mathrm{SD}=1.32)$. This item is the only item that scored high level of mean scores. This indicates that most of the postgraduate students are facing challenges in conducting their collection of data and completing their research during the pandemic, presumably due to the announcement made by the Malaysian government that restricts the people's movement to public areas in effort to minimise the risk of COVID-19 infection. During the enforcement period, research activities such as data collection were delayed for months, which consequently caused delays in the completion of studies. As contended in previous studies, this pandemic had affected students access to the physical library, workstation and laboratory, face-to-face consultation with supervisors, access to field works, attending workshops or academic conferences, and academic networking (Bashar et al., 2020; Mokhatar, 2020). 
Table 2. The mean, standard deviation, and level of academic performance during COVID-19 pandemic

\begin{tabular}{lccc}
\hline \multicolumn{1}{c}{ Items } & Mean & $\begin{array}{c}\text { Standard } \\
\text { Deviation }\end{array}$ & Level \\
\hline $\begin{array}{l}\text { I am facing difficulties in collecting } \\
\text { research data }\end{array}$ & 3.79 & 1.32 & High \\
$\begin{array}{l}\text { There are some personal distractions } \\
\text { during the online study/research }\end{array}$ & 3.57 & 1.32 & Moderate \\
$\begin{array}{l}\text { My study progress has been disrupted } \\
\text { since online learning were introduced } \\
\text { I feel uncomfortable with my study }\end{array}$ & 3.53 & 1.35 & Moderate \\
$\begin{array}{l}\text { environment when I am not in the } \\
\text { university area }\end{array}$ & 3.47 & 1.35 & Moderate \\
$\begin{array}{l}\text { I am having difficulties doing the } \\
\text { research / classes / assignments via } \\
\text { online }\end{array}$ & 3.30 & 1.34 & Moderate \\
$\begin{array}{l}\text { I am not comfortable communicating } \\
\text { with lecturers/supervisors via online }\end{array}$ & 3.28 & 1.37 & Moderate \\
$\begin{array}{l}\text { I could not concentrate on the lecturer / } \\
\text { supervisor during the online meeting }\end{array}$ & 3.25 & 1.34 & Moderate \\
I could not adapt to the new norms of \\
online learning
\end{tabular}

From the results, it is clear that a majority of the postgraduate students agreed that they could adapt to the norms of online learning. It is interesting that the statement of "I could not adapt to the new norms of online learning" scored the lowest mean $(\mu=2.88, \mathrm{SD}=$ 1.26). Such result is probably acquired due to a big number of the respondents (96\%) own a personal gadget or device such as smartphones, PC, laptop, or tablet (see Figure 1 and Figure 2 ), complete with internet access. The result from the current study is found to be in contrast to previous studies conducted by Kapasia et al. (2020), Adnan and Anwar (2020), Yunitasari and Hanifah (2020), Sahu (2020), and Dutta and Smita (2020), in which these studies stated that students have difficulty adapting to online learning. However, the current study also revealed that the respondents could not concentrate during online classes or meetings. It is possible that the students find online classes or meeting to be boring and unengaging because individual attention is a major issued faced in the process of online learning (Dhawan, 2020). Additionally, most of the respondents are using different methods for online learning or for their research (see Figure 3). Although many students are using digital platforms for learning, most of the students face substantial challenges in the process (Kapasia et al., 2020). In a study conduected in West Bengal, India, it is found that $75.9 \%$ students are concerned that the current pandemic situations might cause their academic discontinuation (Kapasia et al., 2020). Therefore, appropriate strategies are urgently needed to ensure that postgraduate students in Malaysia could maintain their academic progress, and each university plays an important role in overcoming these problems. 
INTERNATIONAL JOURNAL OF ACADEMIC RESEARCH IN BUSINESS AND SOCIAL SCIENCES Vol. 11, No. 2, 2021, E-ISSN: 2222-6990 @ 2021 HRMARS

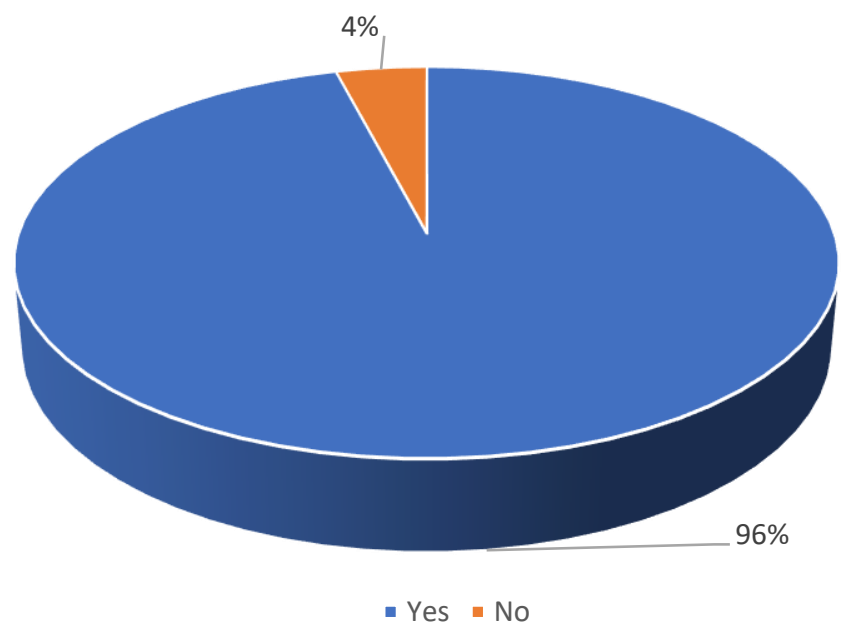

Figure 1. Item 'I have a personal gadget for study purpose'

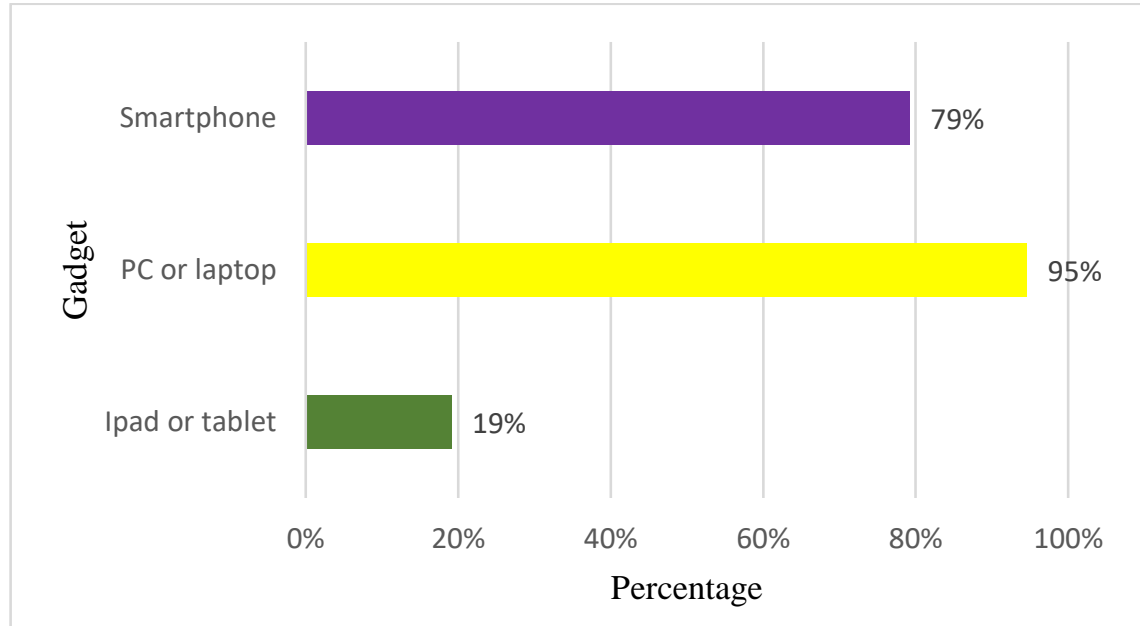

Figure 2. Type of gadget(s) used for online study/research

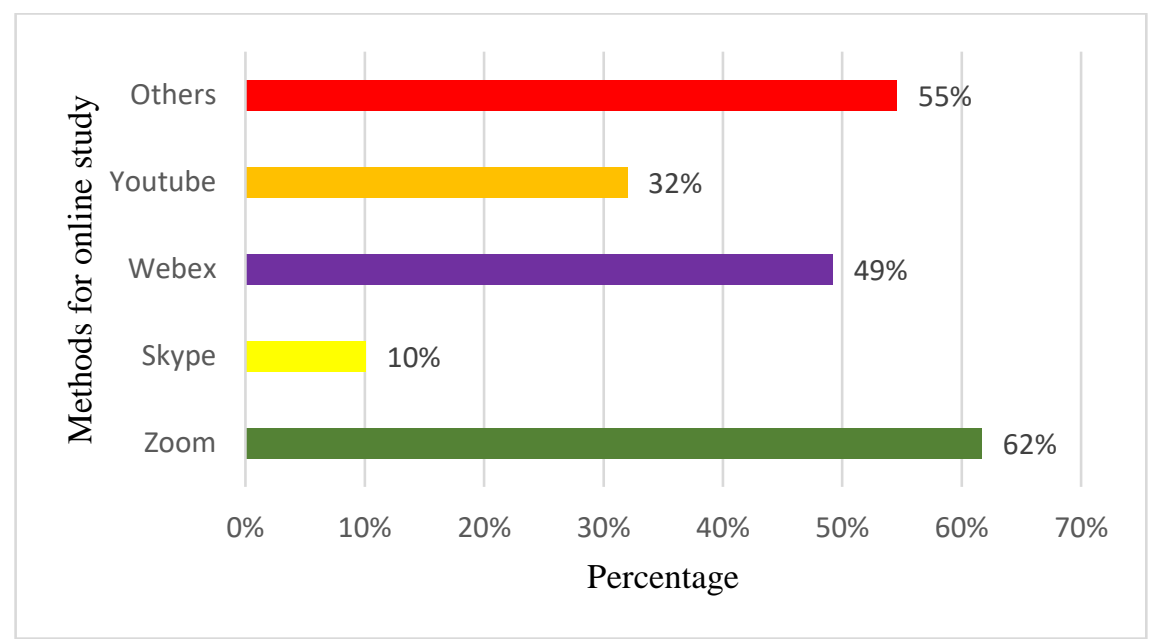

Figure 3. Methods for online study/research 


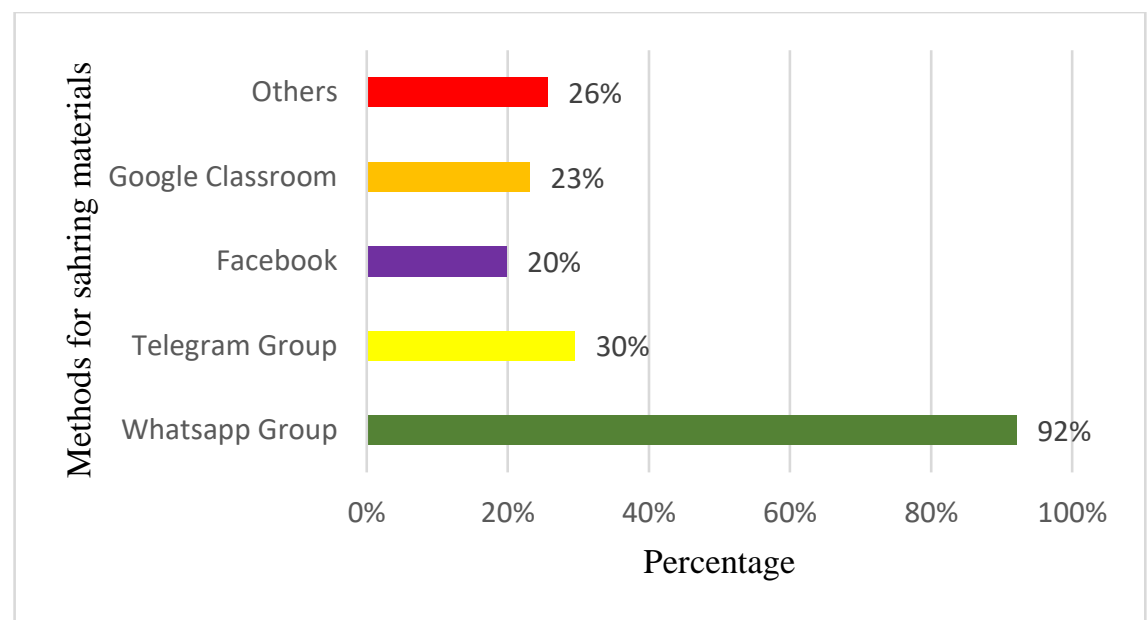

Figure 4. Methods for sharing study/research materials

\section{Financial Stress during COVID-19 Pandemic}

Table 3 displays the mean score in regard to the level of financial stress during COVID19 pandemic among postgraduate students in Malaysia. Majority of the respondents agreed to the first statement; "I plan the use of pocket money carefully" ( $\mu=4.27, S D=0.94)$. This might be influenced by the uncertain economic conditions in Malaysia during this outbreak. As mentioned by Jenei et al. (2020), this pandemic has put students in a very challenging financial situation because there are still many who cannot afford to manage unexpected expenses, resulting in most of the postgraduate students to manage their pocket money wisely. Financial planning is indeed crucial for the students to ensure their academic survival (Huang, 2016). Learning and research process might be disrupted if the students experience financial problems (Bakar et al., 2019). Moreover, the postgraduate students are also more likely to experience stress when faced with financial problems (Asri et al., 2017). On top of that, postgraduate students need to plan their expenses due to academic related financial commitments such as tuition fees, books, internet data, and research materials, therefore encouraging postgraduate students to be financially wise during the pandemic. This is important so that they will not experience any financial problems in the future (Falahati et al., 2011).

Table 3. The mean, standard deviation, and level of financial stress during COVID-19 Pandemic

\begin{tabular}{lccc}
\hline \multicolumn{1}{c}{ Statement } & Mean & $\begin{array}{c}\text { Standard } \\
\text { Deviation }\end{array}$ & Level \\
\hline I carefully plan the use of pocket money & 4.27 & 0.94 & High \\
I have to work on my own to supply my & 3.58 & 1.50 & Moderate \\
$\begin{array}{l}\text { pocket money } \\
\text { I always borrow money from family and }\end{array}$ & 2.36 & 1.50 & Moderate \\
friends & & & \\
\hline
\end{tabular}

It is interesting to note that a majority of the respondents did not agree with the statement "I always borrow money from family and friends to cover my needs" ( $\mu=2.36$, SD $=1.50$ ). This indicates that the respondents are financially sufficient throughout their studies. Based on the respondent's profile, $76 \%$ of the respondents acquire financial resources from full-time jobs, part time jobs, scholarships, and study loans. Although most of the respondents 
are equipped with financial resources during the period of study, it does not mean that they are not affected by financial stress during this pandemic. The pandemic is indeed a burden, and the Recovery Movement Control Order (RMCO) period in Malaysia is announced to be extended until the end of 2020 which would further affect their academic progress, and possibly, their financial stability. To borrow money from family or friends would be an embarrassment; as contented by Ramli and Dawood (2020), university students are embarrassed to ask for money from their parents because of the perception that it will burden and cause inconvenience to their parents.

\section{Social Relationship during COVID-19 Pandemic}

Table 4 shows the mean scores and level of social relationships during COVID-19 pandemic among Malaysian postgraduate students. Our results demonstrated that respondents had high agreement with social relationships statements, showing all mean values from 3.72 to 4.31 . This indicates that a majority of the respondents do not have any social relationship issues in their daily life during the pandemic, despite having issues with their academic performance and financial stability. This finding is revealed to be inconsistent with the study by Baloran (2020) that claimed $54 \%$ to $46 \%$ of the students avoid social contact, meetings, and gatherings. This finding is also not in line with the findings from Roy et al. (2020) which reported that many individuals have major concern upon themselves and their families during COVID-19. This study indicates that Malaysian postgraduate students do not have limited social contact, they are likely to engage or communicate with their supervisors, families and friends.

Table 4. The mean, standard deviation, and level of social relationships during COVID-19 pandemic

\begin{tabular}{lccc}
\hline \multicolumn{1}{c}{ Statement } & Mean & $\begin{array}{c}\text { Standard } \\
\text { Deviation }\end{array}$ & Level \\
\hline $\begin{array}{l}\text { My family/spouse gave me encouragement in } \\
\text { my studies }\end{array}$ & 4.31 & 0.91 & High \\
$\begin{array}{l}\text { My family/spouse understands my job as a } \\
\text { postgraduate student }\end{array}$ & 4.30 & 0.95 & High \\
$\begin{array}{l}\text { The supervisor gave me good guidance } \\
\text { throughout my online studies }\end{array}$ & 3.98 & 0.97 & High \\
$\begin{array}{l}\text { My supervisor and I regularly communicate for } \\
\text { study purposes } \\
\text { I often interact and exchange views with } \\
\text { classmates }\end{array}$ & 3.76 & 1.07 & High \\
\hline
\end{tabular}

\section{Association between Academic Performance, Financial Stress and Social Relationships during COVID-19 Pandemic}

Bivariate correlations were calculated to examine the relationship between three variables (academic performance, financial stress, and social relationship) and it is presented in Table 5. It is found that academic performance was positively correlated with the financial stress $(r=0.202, p<0.01)$ and negatively correlated with social relationships $(r=-0.314, p<$ 0.01) among postgraduate students during pandemic. However, based on Pearson Correlation generated by SPSS, there is no significant correlation between financial stress and 
social relationships. These postgraduate students may find difficulties in planning their financials because money management as a postgraduate student is conceivably complicated. Others have shown that financial stress is related to academic performance. Adeoye-Agboola and Evans (2015) in their study found that anxiety or stress could influence students on their academic performance through their financials. Moreover, financial factors may also contribute to psychological distress of university students regardless of gender (Vasugi \& Hassan, 2019). However, the present study revealed that, as the financial stress increases, the social relationship between postgraduate students and their family, friends and supervisors become weaker. This indicates that when the students are facing financial problems, they do not seek help from their family or acquaintances, which would not only affect their academic performance, but consequently, their mental health. This is a significant finding in the attempt to understand of the impact of COVID-19 pandemic on academic survival among postgraduate students in Malaysia. This provides a good starting point for discussion and further research on how these issues can be tackled during the pandemic.

Table 5. Correlations between variables

\begin{tabular}{llccc}
\hline & & $\begin{array}{c}\text { Academic } \\
\text { Performance }\end{array}$ & $\begin{array}{c}\text { Financial } \\
\text { Stress }\end{array}$ & $\begin{array}{c}\text { Social } \\
\text { Relationships }\end{array}$ \\
\hline Academic & Pearson & 1 & $.202^{* *}$ & $-.314^{* *}$ \\
Performance & Correlation & & & \\
& Sig. (2-tailed) & & .000 & .000 \\
& $\mathrm{~N}$ & 606 & 606 & 606 \\
Financial Stress & Pearson & $.202^{* *}$ & 1 & -.073 \\
& Correlation & & & .073 \\
& Sig. (2-tailed) & .000 & & 606 \\
Social & $\mathrm{N}$ & 606 & 606 & 1 \\
Relationships & Pearson & $-.314^{* *}$ & -.073 & \\
& Correlation & & & \\
& Sig. (2-tailed) & .000 & .073 & 606 \\
\hline
\end{tabular}

Note. ${ }^{* *}$ Correlation is significant at the 0.01 level (2-tailed)

\section{Conclusion}

In a nutshell, the COVID-19 pandemic caused major concerns among Malaysian postgraduate students. In this study, we have addressed academic performance, financial stress, social relationship, and their impact on Malaysian postgraduate students during COVID-19 pandemic in 2020, through the analysis of survey questionnaires. The study's findings can be summarised as follows. Firstly, the results suggest that Malaysian postgraduate students have moderate academic performance, even though they could adapt to the new norms of online learning. Secondly, a majority of the students are facing financial stress brought about by the uncertain economic conditions in Malaysia during this outbreak. Thirdly, our findings also show that good academic performance increases financial stress among postgraduate students yet reduces social interaction. This shows that Malaysian postgraduate students are facing challenges in completing their studies during the outbreak. COVID-19 has undoubtedly affected the academic survival of most postgraduate students in Malaysia, especially in terms of academic performance and financial stress. 
Thus, appropriate strategies and actions are urgently needed to ensure that postgraduate students in Malaysia could maintain their academic progress, for every university plays a crucial role in overcoming such predicament. For instance, a well-designed guideline should be implemented to supervise for academic continuity during and after an outbreak. It is important to remain in touch with the postgraduate students, and more attention needs to be paid to their performance during discussions or online learning. Besides, higher education institutions should provide psychological services, social, and financial support, as they should mitigate the psychological impacts on students. Also, delivery of more accurate, clear, and consistent information to the students is recommended, such as information regarding accessibility in and out the campus, and this will benefit them in terms of their wellbeing and their readiness to return to thew campus to continue their studies, lab works, and other activities.

Furthermore, the higher education institutions could launch an intervention using a digital platform, for instance, a chatbox that can connect them with the students at any time. The students can express their awareness or pose any questions regarding the situation, making them feel appreciated. It is very crucial to care for their wellbeing, as well as their academic performances. This would indicate that the students are not be neglected by their institutions. Therefore, this study is reckoned as one of the important pieces of evidence that has contributed to the higher education system in Malaysia regarding the postgraduates' current state. This study is anticipated to contribute to the body of knowledge to strengthen the existing literature further, and more studies on this issue are expected in the future.

\section{Acknowledgement}

Acknowledgement is extended to all postgraduate students who were involved as respondents and reviewers for spending their time and effort in reviewing and providing constructive comments to make this study successful. Many thanks to Dr. Mohamed Nazreen Shahul Hamid, Dr. Mohamad Hafifi Jamri, Ms. Nur Syuhada Mustakim, and Ms. Syazana Ayuni Shaharudin, who helped in technical matters.

\section{References}

Adeoye-Agboola, D. I., \& Evans, H. (2015). The relationship between anxiety and academic performance of postgraduate international students in a British university: A crosssectional quantitative design. Science Journal of Public Health, 3(3), 331-338. https://dx.doi.org/10.11648/j.sjph.20150303.15

Adnan, M., \& Anwar, K. (2020). Online learning amid the COVID-19 pandemic: Students' perspectives. Journal of Pedagogical Sociology and Psychology, 2(1), 45-51. http://www.doi.org/10.33902/JPSP.\%202020261309

Al-Hassani, H. Q. M. H., Khakimova, N., \& Alfadaa, F. I. (2020). The factors affecting online purchase intention among university students in Malaysia: A quantitative study during COVID-19. Journal of Critical Reviews, 7(16), 3464-3477. http://dx.doi.org/10.31838/jcr.07.16.443

Ana, A., Minghat, A. D., Purnawarman, P., Saripudin, S., Muktiarni, M., Dwiyanti, V., \& Mustakim, S. S. (2020). Students' perceptions of the twists and turns of e-learning in the midst of the COVID-19 outbreak. Revista Romaneasca Pentru Educatie Multidimensionala, 12(1Sup2), 15-26. https://doi.org/10.18662/rrem/12.1sup1/242 
Aristovnik, A., Kerzic, D., Ravselj, D., Tomazevic, N., \& Umek, L. (2020). Impacts of the COVID19 pandemic on life of higher education students: A global perspective. Sustainability, 12(20), 1-34. https://doi.org/10.3390/su12208438

Bakar, N.A., Asri, N.M., Laili, I.A., \& Saad, S. (2019). Masalah kewangan dan tekanan dalam kalangan mahasiswa (Financial problems and stress among female university students). Jurnal Personalia Pelajar, 22(2), 113-120.

Baloran, E.T. (2020). Knowledge, attitudes, anxiety, and coping strategies of students during COVID-19 pandemic. Journal of Loss and Trauma, 25(8), 635-642. https://doi.org/10.1080/15325024.2020.1769300

Bashar, S.I., Inda, A., \& Maiwada, R.M. (2020). Perceived effects of corona-phobia and movement control order on Nigerian postgraduate students in Universiti Teknologi Malaysia. Asia Proceedings of Social Sciences 6(2), 117-120. https://doi.org/10.31580/apss.v6i2.1307

Chung, E., Subramaniam, G., \& Dass, L.C. (2020). Online learning readiness among university students in Malaysia amidst COVID-19. Asian Journal of University Education, 16(2), 4658. https://doi.org/10.24191/ajue.v16i2.10294

Chyr, W. L., Shen, P. D., Chiang, Y. C., Lin, J. B., \& Tsai, C. W. (2017). Exploring the effects of online academic help-seeking and flipped learning on improving students' learning. Journal of Educational Technology \& Society, 20(3), 11-23.

Dawood, S. R. S., Ramli, M. W., \& Som, S. H. M. (2020). The resilience of senior citizens in the era of the pandemic: A preliminary study during the movement control order (MCO) in Penang, Malaysia. GEOGRAFI, 8(2), 110-128.

Dhawan, S. (2020). Online learning: A panacea in the time of COVID-19 crisis. Journal of Educational Technology Systems, 49(1), 5-22. http://dx.doi.org/10.1177/0047239520934018

Dutta, S., \& Smita, M.K. (2020). The impact of COVID-19 pandemic on tertiary education in Bangladesh: Students' perspectives. Open Journal of Social Sciences, 8(9), 53-68. https://doi.org/10.4236/jss.2020.89004

Falahati, L., Paim, L., Ismail, M., Haron, S.A., \& Masud, J. (2011). Assessment of university students' financial management skills and educational needs. African Journal of Business Management, 5(15), 6085-6091. https://doi.org/10.5897/AJBM10.1583

Gonzalez, T., de la Rubia, M.A., Hincz, K.P., Comas-Lopez, M., Subirats, L., Fort, S., \& Sacha, G.M. (2020). Influence of COVID-19 confinement on students' performance in higher education. PloS ONE, 15(10), 1-23. https://doi.org/10.1371/journal.pone.0239490

Grubic, N., Badovinac, S., \& Johri, A.M. (2020). Student mental health in the midst of the COVID-19 pandemic: A call for further research and immediate solutions. International Journal of Social Psychiatry, 66(5), 517-518. https://doi.org/10.1177\%2F0020764020925108

Huang, L. (2016). Personal financial planning for college graduates. Technology and Investment, 7(3), 123-134. http://dx.doi.org/10.4236/ti.2016.73014

Hussiin, H. (2020). Kesan COVID-19 kepada pelajar UMP: Satu kajian ringkas. Universiti Malaysia Pahang News. Retrieved from http://news.ump.edu.my/experts/kesan-covid19-kepada-pelajar-ump-satu-kajian-ringkas

Jenei, K., Cassidy-Mathews, C., Virk, P., Lulie, B., \& Closson, K. (2020). Challenges and opportunities for graduate students in public health during the COVID-19 pandemic. Canadian Journal of Public Health, 111(3), 408-409. https://doi.org/10.17269/s41997020-00349-8 
Kapasia, N., Paul, P., Roy, A., Saha, J., Zaveri, A., Mallick, R., Barman, B., Das, P., \& Chouhan, P. (2020). Impact of lockdown on learning status of undergraduate and postgraduate students during COVID-19 pandemic in West Bengal, India. Children and Youth Services Review, 116, 1-5. https://doi.org/10.1016/j.childyouth.2020.105194

Kaur, G. (2020). Digital life: Boon or bane in teaching sector on COVID-19. CLIO an Annual Interdisciplinary Journal of History, 6(6), 416-427.

Khan, A. H., Sultana, M. S., Hossain, S., Hasan, M. T., Ahmed, H. U., \& Sikder, M. T. (2020). The impact of COVID-19 pandemic on mental health \& wellbeing among home-quarantined Bangladeshi students: A cross-sectional pilot study. Journal of Affective Disorders, 277, 121-128. https://doi.org/10.1016/j.jad.2020.07.135

Kong, S. C. (2019). Partnership among schools in e-Learning implementation: Implications on elements for sustainable development. Journal of Educational Technology \& Society, 22(1), 28-43.

Landell, K. (1997). Management by menu. London: Wiley and Sons Inc.

Mahdy, M. A. A. (2020). The impact of COVID-19 pandemic on the academic performance of veterinary medical students. Frontiers in Veterinary Science. 7, 1-8. https://doi.org/10.3389/fvets.2020.594261

Mahmood, S. (2020). Instructional strategies for online teaching in COVID-19 pandemic. Human Behavior and Emerging Technologies, 1-5. https://doi.org/10.1002/hbe2.218

Ministry of Health Malaysia. (2021). Kenyataan akhbar KPK 12 Januari 2021 - Situasi semasa jangkitan penyakit coronavirus 2019 (COVID-19) di Malaysia. Retrieved from https://kpkesihatan.com/2021/01/12/kenyataan-akhbar-kpk-12-januari-2021-situasisemasa-jangkitan-penyakit-coronavirus-2019-covid-19-di-malaysia/

Mokhatar, S. N. (2020). Ancaman COVID-19, aktiviti penyelidikan terhenti atau perlu diteruskan?. Universiti Tun Hussein Onn Malaysia News. Retrieved from https://news.uthm.edu.my/ms/2020/05/ancaman-covid-19-aktiviti-penyelidikanterhenti-atau-perlu-diteruskan/

Mostafa, L. (2020). Egyptian student sentiment analysis using Word2vec during the coronavirus (COVID-19) pandemic. In Hassanien A.E., Slowik A., Snášel V., El-Deeb H., Tolba F.M. (eds). International Conference on Advanced Intelligent Systems and Informatics (pp. 195-203). Springer, Cham.

Mpungose, C. B. (2020). Emergent transition from face-to-face to online learning in a South African University in the context of the Coronavirus pandemic. Humanities and Social Sciences Communications, 7(1), 1-9. https://doi.org/10.1057/s41599-020-00603-x

Nik-Ahmad-Zuky, N. L., Baharuddin, K. A., \& Rahim, A. F. A. (2020). Online clinical teaching and learning for medical undergraduates during the COVID-19 pandemic: The Universiti Sains Malaysia (USM) experience. Education in Medicine Journal, 12(2), 75-80. https://doi.org/10.21315/eimj2020.12.2.8

Ramli, M. W., \& Dawood, S. R. S. (2020). Faktor tekanan dalam kalangan pelajar Universiti Sains Malaysia: Satu tinjauan awal (Stress factors among Universiti Sains Malaysia students: A preliminary survey). e-Bangi: Journal of Social Sciences and Humanities, 17(7), 66-76.

Roy, D., Tripathy, S., Kar, S. K., Sharma, N., Verma, S. K., \& Kaushal, V. (2020). Study of knowledge, attitude, anxiety \& perceived mental healthcare need in Indian population during COVID-19 pandemic. Asian Journal of Psychiatry, 51, 1-7. https://doi.org/10.1016/j.ajp.2020.102083 
Sahu, P. (2020). Closure of universities due to Coronavirus Disease 2019 (COVID-19): Impact on education and mental health of students and academic staff. Cureus, 12(4), 1-6. https://dx.doi.org/10.7759\%2Fcureus.7541

Salleh, F. I. M., Ghazali, J. M., Ismail, W. N. H. W., Alias, M., \& Rahim, N. S. A. (2020). The impacts of COVID-19 through online learning usage for tertiary education in $\begin{array}{llll}\text { Malaysia. Journal of } & \text { Critical } & \text { Reviews, 7(8), } & \end{array}$ http://dx.doi.org/10.31838/jcr.07.07.01

Shahzad, A., Hassan, R., Aremu, A. Y., Hussain, A., \& Lodhi, R. N. (2020). Effects of COVID-19 in E-learning on higher education institution students: the group comparison between male and female. Quality \& Quantity, 1-22. https://doi.org/10.1007/s11135-02001028-z

Sundarasen, S., Chinna, K., Kamaludin, K., Nurunnabi, M., Baloch, G. M., Khoshaim, H. B., Hossain, S. F. A., \& Sukayt, A. (2020). Psychological impact of COVID-19 and lockdown among university students in Malaysia: Implications and policy recommendations. International Journal of Environmental Research and Public Health, 17(17), 1-13. https://doi.org/10.3390/ijerph17176206

Toquero, C. M. (2020). Challenges and opportunities for higher education amid the COVID-19 pandemic: The Philippine context. Pedagogical Research, 5(4), 1-5. https://doi.org/10.29333/pr/7947

United Nations Educational, Scientific and Cultural Organization (UNESCO). Education: From disruption to recovery. Retrieved from https://en.unesco.org/covid19/educationresponse

United Nations Educational, Scientific and Cultural Organization, International Institute for Higher Education in Latin America and the Caribbean (UNESCO IESALC). (2020). COVID19 and higher education: Today and tomorrow. Retrieved from http://www.iesalc.unesco.org/en/wp-content/uploads/2020/04/COVID-19-EN090420-2.pdf

Vasugi, S., \& Hassan, N. C. (2019). Depression, anxiety and stress among postgraduate students in faculty of education of a public university in Malaysia. Malaysian Journal of Medicine and Health Sciences, 15(SUPP1), 90-95.

Wang, L., \& DeLaquil, T. (2020). The isolation of doctoral education in the times of COVID-19: Recommendations for building relationships within person-environment theory. Higher Education \& Research Development, 39(7), 1-5. https://doi.org/10.1080/07294360.2020.1823326

World Health Organization (WHO). (2020). Timeline of WHO's response to COVID-19. Retrieved from https://www.who.int/news/item/29-06-2020-covidtimeline

Yunitasari, R., \& Hanifah, U. (2020). Pengaruh pembelajaran daring terhadap minat belajar siswa pada masa COVID-19. Edukatif: Jurnal IImu Pendidikan, 2(3), 232-243. https://doi.org/10.31004/edukatif.v2i3.142 